
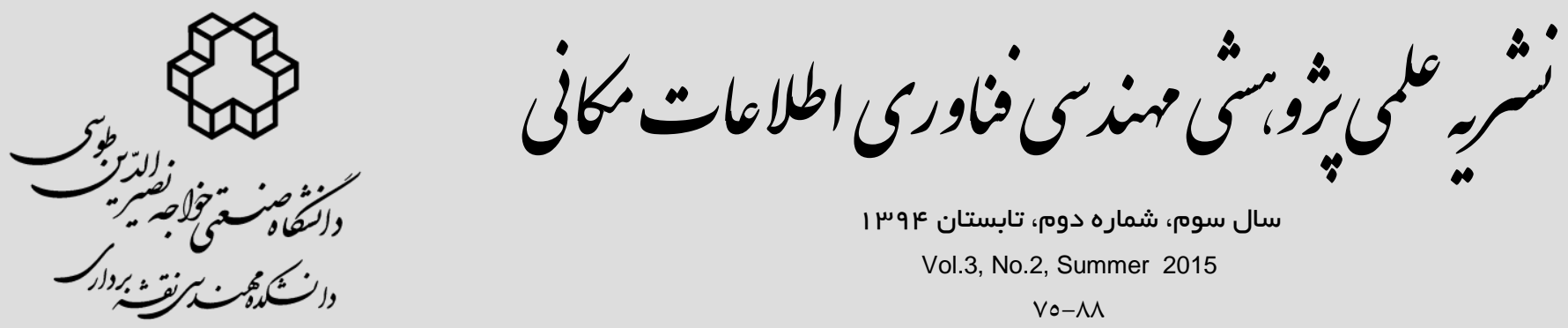

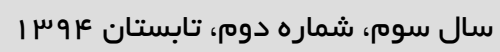
Vol.3, No.2, Summer 2015

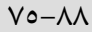

ارائه يك روش انتخاب ويثزى براساس الكوريتهم زنتيك و درخت تصميم بهمنظور طبقهبندى

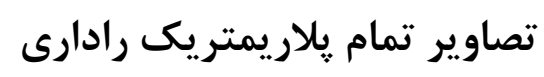

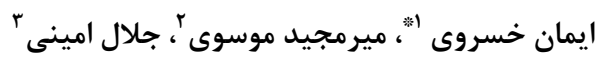

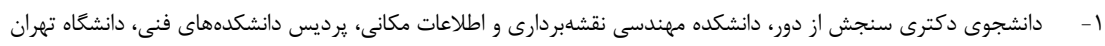

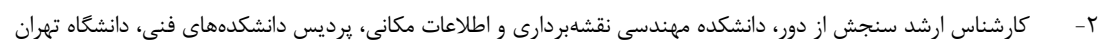

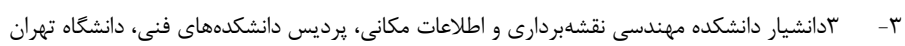

تاريخ دريافت مقاله:

جكيده

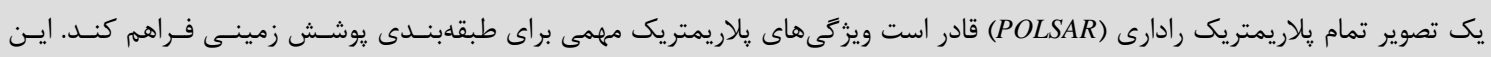

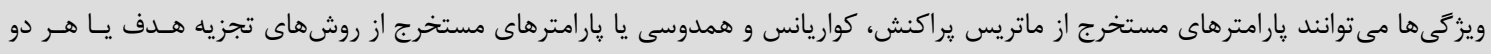

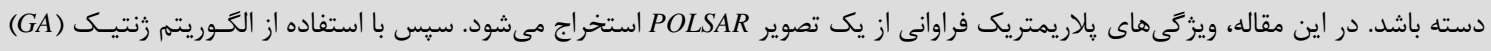

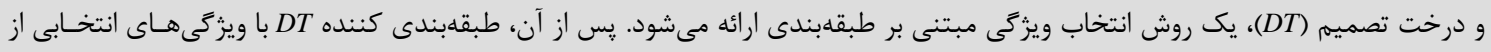

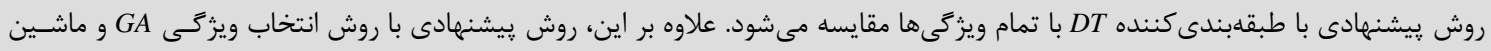

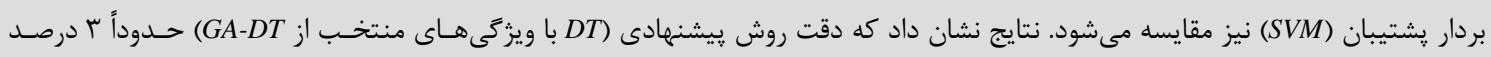

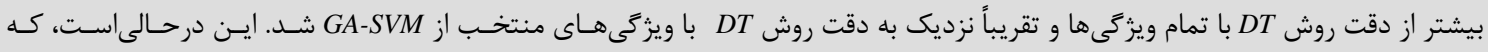

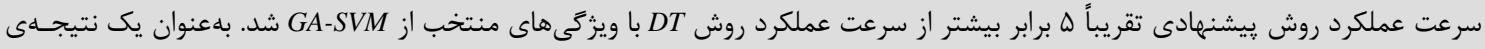

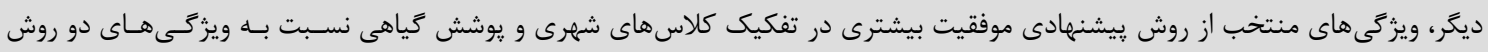
ديگر داشتند.

كليدوازهها: انتخاب ويزَىى، الكوريته رنتيك (GA)، درخت تصميم (DT)، طبقهبندى، تصاوير تمام پِاريمتريك، رادار.

نويسنده مكاتبه كننده: خيابان كاركًر شمالى (اميرآباد)، يرديس دانشكدههاى فنى، دانشكده مهيندسى نقشهبردارى و اطلاعات مكانى، كروه سنجش از دور. Email: iman.khosravi@ut.ac.ir 


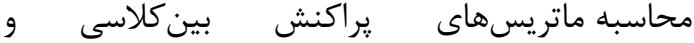
درون كلاسى ارائهشد [TII]]. در مقاله حدادى و همكاران

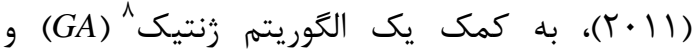
طبقهبندى كننده NN و در مقاله صالحى و همكاران

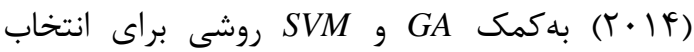

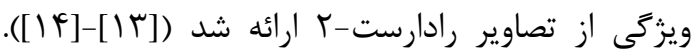

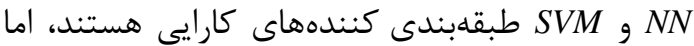
NN اجراى شبكه، به يك جواب غيرمشابه با جواب قبلى دئى مىرسد. SVM با وجود توليد نتايج منحصربهفرد، اما به به

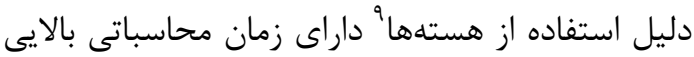

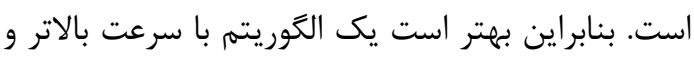
كارايى مشابه با اين روشها در نظر ترفت. در مقاله كى الى بلى

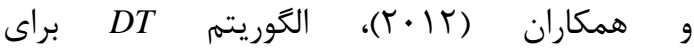

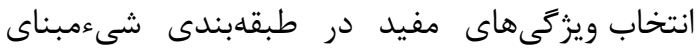
تصاوير POLSAR استفاده شد معايد الكوريتم داراى سرعت بالاترى نسبت به NN است. اما تركيب روش GA و ويزگى تصاوير POLSAR استفاده نشده است. تركيب قوه ابتكارى الكوريتم GA و و سرعت الكوريتم DT

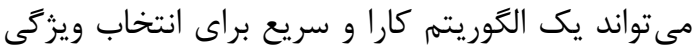
از تصاوير POLSAR ابعاد بالا ارائهدهد. بنابراين اين يزوهش به دنبال آن است تا به جاى

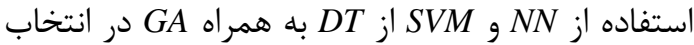
ويزگى تصاوير POLSAR بهره بخيرد. همانطور كه در رايان مقاله مشاهده خواهد شد، روش يُ بيشنهادى از

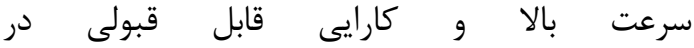
انتخاب ويزگى تصاوير POLSAR برخوردار است.

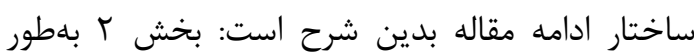

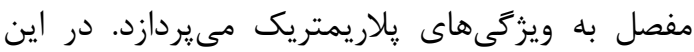
بخش، دو دسته ويزگى هاى مستخرج از داده اصلى و

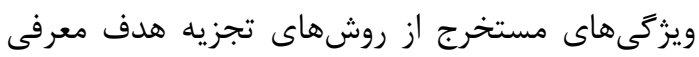

\footnotetext{
${ }^{8}$ Genetic Algorithm

${ }^{9}$ Kernel
}

| - 1- مقدمه

از يك تصوير تمام يلاريمتريك رادارى (POLSAR)،

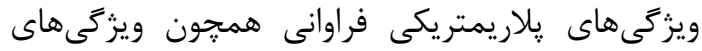

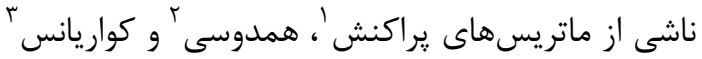

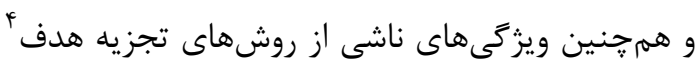
در يايه يُلاريزاسيون خطى و دايرهاى قابل استخراج

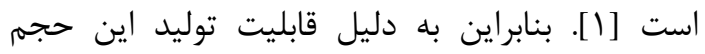
بالاى اطلاعات، يكى از مهمترين كاربردهاى اين تصاوير طبقهبندى يوشش زمينى است. تاكنون، الكَوريتمهاى آلاي تصائ نظارتشده و نظارتنشده متعددى از جمله روشهاى بيشينه شباهت، فازى سىمينز، ويشارت، درخت

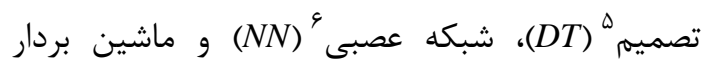

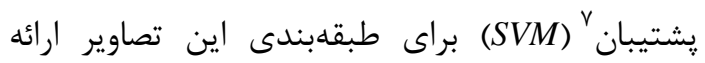

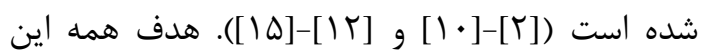
مطالعات، نشان دادن قابليت بهكاركيرى مؤثر ويزگى هاى يلاريمتريك فراوان مستخرج از تصاوير POLSAR در طبقهبندى يوشش زمينى بوده است.

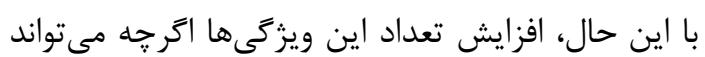
منجر به توليد دقت بالايى در طبقهبندى شود، اما بلهور همزمان ممكن است باعث ييجيدهتر شدن

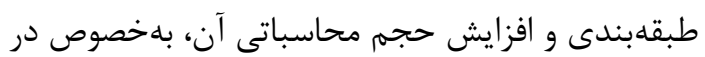
روشهاى يارامتريك شود. بهَّونهاى كه در زمان

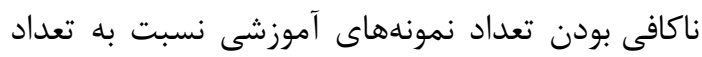

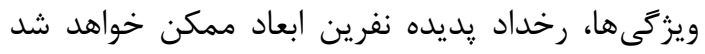

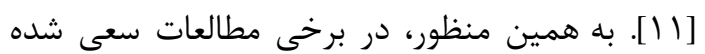

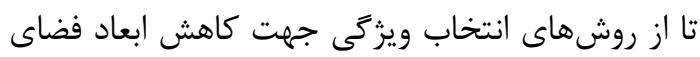
ويزگى اين تصاوير استفاده شود. در مقاله مقصودى و

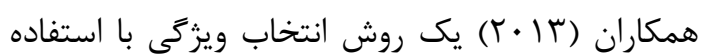

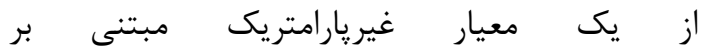

\footnotetext{
${ }^{1}$ Scattering

2 Coherency

${ }^{3}$ Covariance

${ }^{4}$ Target Decomposition

${ }^{5}$ Decision Tree

${ }^{6}$ Neural Network

${ }^{7}$ Support Vector Machine
} 
ץ-ا. ويزگى هاى يلاريمتريك مستخرج از داده

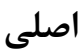
مهمترين ويزَى ها و شاخصهاى مستخرج از داده اصلى يا به عبارتى از عناصر ماتريس يراكنش كه در در

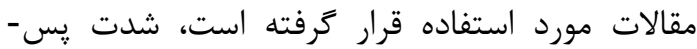

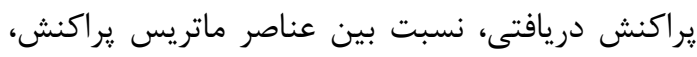

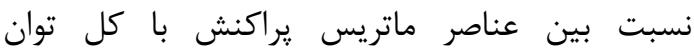
براكنشيافته و ضريب همبستخى بين قطبشهاى برائ يلاريمتر يك است.
مىشود. سيس در بخش זّ، داده و منطقه مطالعاتى و

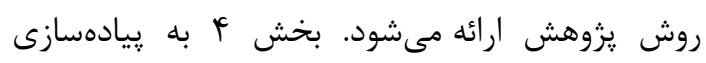
روشها و بررسى و مقايسه نتايج مربوط مىيردازد. درنهايت، بخش ه به نتيجه كيرى مقاله ختم مىشود. r. ويزكى هاى يلاريمتريك

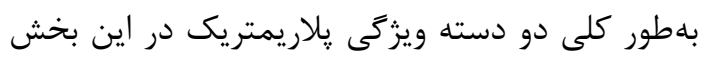

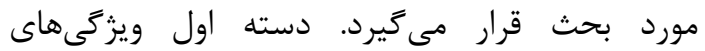
يلاريمتريكى كه مستقيم از داده اصلى يا به عبارتى از

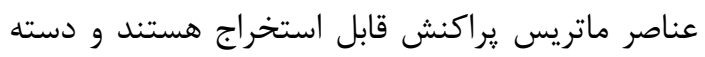

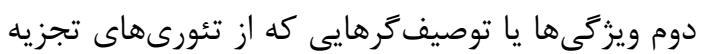

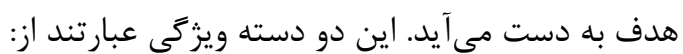

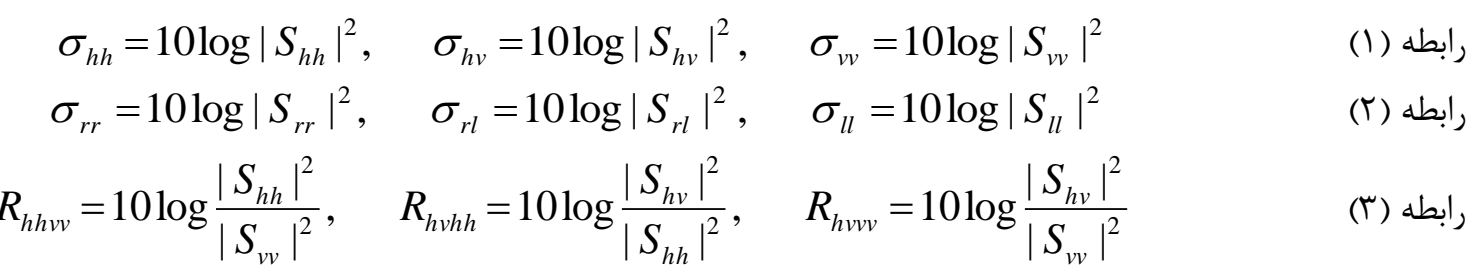

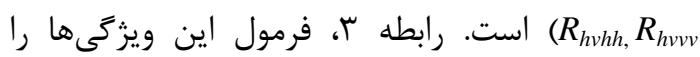
نشان مى دهد [IV] اين ويزگىها در تخمين كميتهاى هواشناسى مانند تعيين اندازه قطرات باران و شدت بارش كاربرد فراوانى

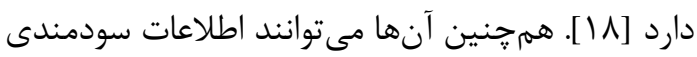

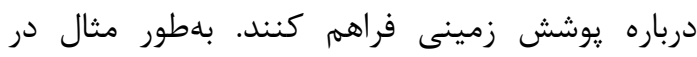

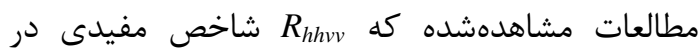
تعيين ميزان زبرى سطوح زمينى است [9 [19]. همرجنين با توجه به تئورى تركيب يلاريزاسيون، نسبت قطبشهاى پِاريمتريك در بايه دايرهاى ( (R rlll

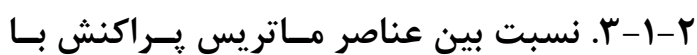
كل توان يراكنشيافته ويزگگهاى قابل تعريف ديخر با عناصر ماتريس يراكنش، نسبت هر قطبش קيلاريمتريك به كل توان

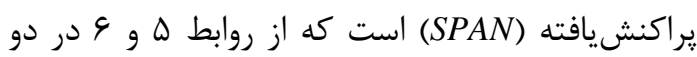
يايه خطى $\left(R_{r r}, R_{r l}, R_{l l}\right)$ و داير قابل محاسبه است [• [r]

\section{r-1-1. شدت يس پيراكنش دريافتى}

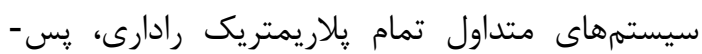

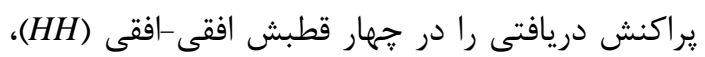
قائم-قائم (VV)، افقى -قائم (HV) و قائم-افقى (VH) ذخيره مى كند. بنابراين سادهترين ويزّكى قابل استخراج

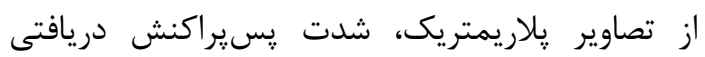
است [9]]. هم:جنين با داشتن ماتريس براكنش در بايه خطى افقى و قائم $)$

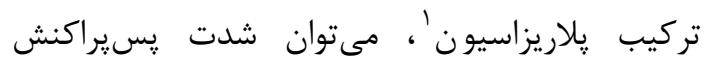

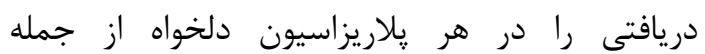
يلاريزاسيون دايرهاى $)$ ا و r، فرمول شدت يسيراكنش دريافتى در پايه خطى و وايرهاى $\left(\sigma_{h h}, \sigma_{h v,} \sigma_{v h}\right)$ r-1-1. نسبت بين عناصر ماتريس يراكنش

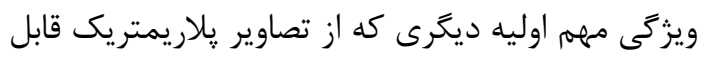

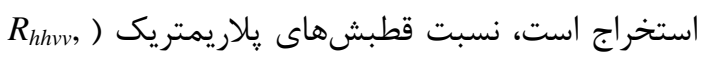

${ }^{1}$ Polarization Synthesis 


$$
\begin{aligned}
& R_{r r l l}=10 \log \frac{\left|S_{r r}\right|^{2}}{\left|S_{l l}\right|^{2}}, \quad R_{r l r r}=10 \log \frac{\left|S_{r l}\right|^{2}}{\left|S_{r r}\right|^{2}}, \quad R_{r l l l}=10 \log \frac{\left|S_{r l}\right|^{2}}{\left|S_{l l}\right|^{2}} \quad \text { ( ) } \\
& R_{h h}=\frac{\left|S_{h h}\right|^{2}}{S P A N}, \quad R_{h v}=\frac{\left|S_{h v}\right|^{2}}{S P A N}, \quad R_{v v}=\frac{\left|S_{v v}\right|^{2}}{S P A N} \\
& \text { رابطه (a) } \\
& R_{r r}=\frac{\left|S_{r r}\right|^{2}}{S P A N}, \quad R_{r l}=\frac{\left|S_{r l}\right|^{2}}{S P A N}, \quad R_{l l}=\frac{\left|S_{l l}\right|^{2}}{S P A N}
\end{aligned}
$$

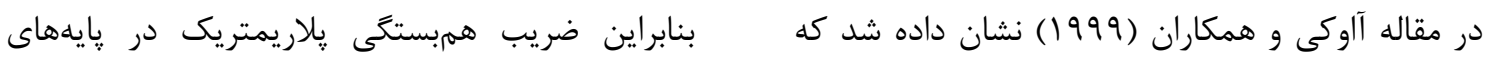
خطى و دايرهاى ويزگى هاى مناسبى براى تفكيك و ونائ

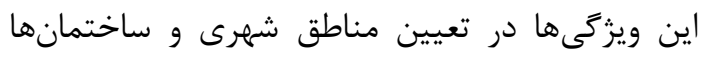
طبقلبندى يوششهاى گياهى مختلف است [V].

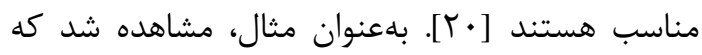

ץ-1-1. ويثَى هاى ناشى از ماتريس مولر

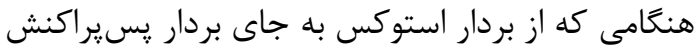

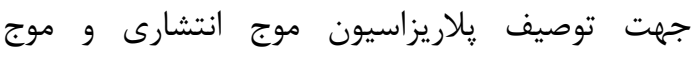

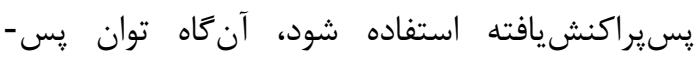

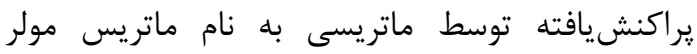
(به جاى ماتريس يسيراكنش) قابل تعريف است. بردار

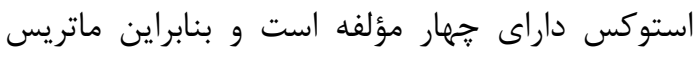
مولر كه توسط اين بردار ساخته مىشود، يك ماتريس

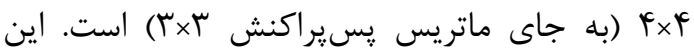

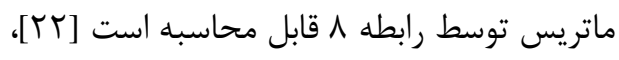
$M=A^{*}\left(S \otimes S^{*}\right) A^{-1}, \quad A=\left[\begin{array}{cccc}1 & 0 & 0 & 1 \\ 1 & 0 & 0 & -1 \\ 0 & 1 & 1 & 0 \\ 0 & j & -j & 0\end{array}\right]_{(\text {) }}$ كه در آن رابطه، S ماتريس يراكنش است. بنابر اين هر عنصر ماتريس استوكس مىتواند از عناصر ماتريس يراكنش محاسبه شود كه جهار عنصر مهاتهم قطرى آن آن

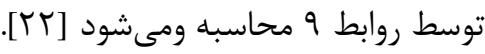

(9)

$$
\begin{aligned}
& M_{11}=\frac{1}{4}\left\{S_{h h} S_{h h}^{*}+S_{v v} S_{v v}^{*}+2 S_{h v} S_{h v}^{*}\right\} \\
& M_{22}=\frac{1}{4}\left\{S_{h h} S_{h h}^{*}+S_{v v} S_{v v}^{*}-2 S_{h v} S_{h v}^{*}\right\} \\
& M_{33}=\frac{1}{2} S_{h v} S_{h v}^{*}+\frac{1}{2} \operatorname{Re}\left\{S_{h h} S_{v v}^{*}\right\} \\
& M_{44}=\frac{1}{2} S_{h v} S_{h v}^{*}-\frac{1}{2} \operatorname{Re}\left\{S_{h h} S_{v v}^{*}\right\}
\end{aligned}
$$

در مناطقى كه داراى ساختمانهاى جوبى با ديوارهاى عمود بر خط ديد رادار است، مقدار يارامتر بسيار بالاست. همرجنين در مناطقى كه ساختمانهاى

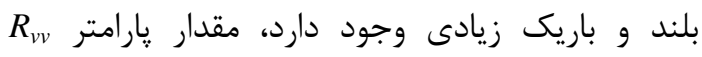

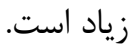
Y-1F-

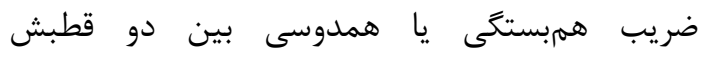
يلاريمتريك از رابطه

$\rho_{X Y, A B}=\left|\frac{\left\langle S_{X Y} \cdot S_{A B}^{*}\right\rangle}{\sqrt{\left\langle S_{X Y} \cdot S_{X Y}^{*}\right\rangle \cdot\left\langle S_{A B} \cdot S_{A B}^{*}\right\rangle}}\right|$ (V) رابطه قابل محاسبه است كه در آن، XY و AB نمايان يلاريزاسيون قطبش هاست.

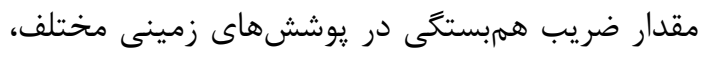

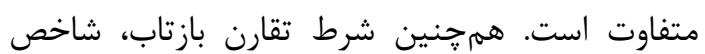

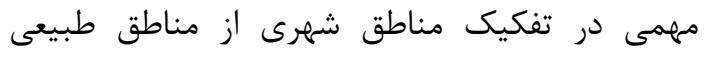

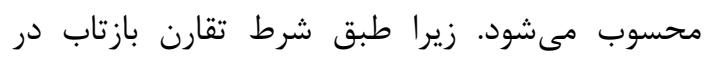
مناطق طبيعى، رابطه من من من

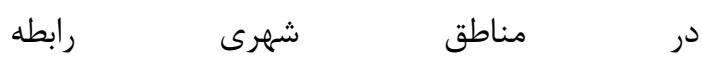

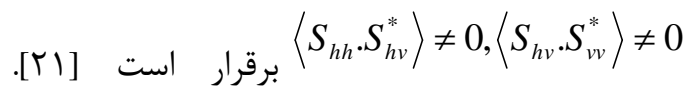

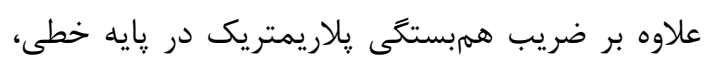

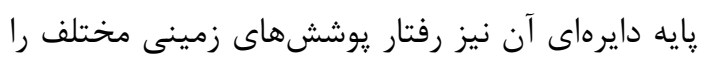

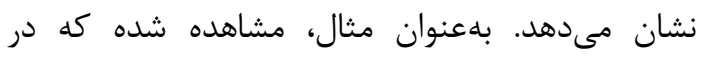
مناطق جنَلى رابطه 
توجيهشده در fd درجه يا مكانيسم حجمى (شبيه

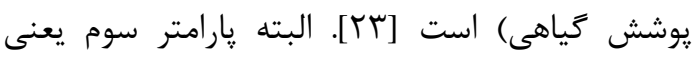
توان يراكنشيافته از هدفهاى با مكانيسم يراكنش حجمى همربستگى شديدى با ويزگى شدت يسيراكنش دريافتى

\section{r-r-r.r. ضرايب تجزيه كروكاگر}

ضرايب حاصل از تجزيه كروكاتر، توان يراكنشيافته از

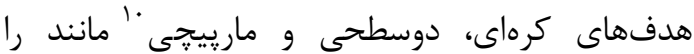
بيان مى كند كه از رابطه 11 1 قابل محاسبه است كه در آن

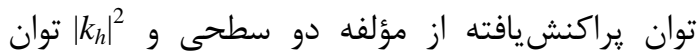
يراكنشيافته از مؤلفه مارييجى ماتريس يراكنش است

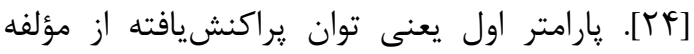
كرهاى مانند يعنى |2 $\left.\right|^{2}$

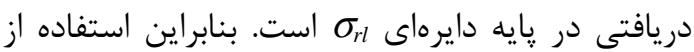

$$
\text { آن اضافى به نظر مىرسد. }
$$

\section{r-r-r. ضرايب تجزيه فريمن}

روش تجزيه غيرهمدوس فريمن، ماتريس كواريانس را

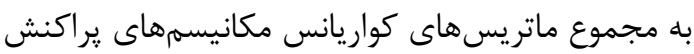

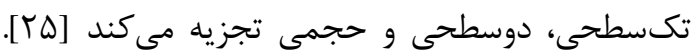
بنابراين مىتوان توانهاى : يراكنشيافته از اين نوع هدفها را بهعنوان ويزگى درنظر گرفت. در اينجا نيز مؤلفه توان يراكنش يافته از هدف هايى با مكانيسم

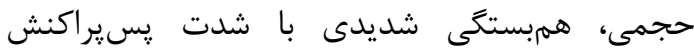
دريافتى توان :راكنشيافته از هدف هايى با مكانيسم تكسطحى دانى و دوسطحى از رابطه r ا قابل محاسبه است.
اين جهار مؤلفه نيز به نوعى توان يسيراكنشيافته را نشان مى دهد.

r-r. ويزگكىهاى مســتخرج از روشهـــ تجزيـهـ

هدف

ويزگىهاى استخراجى از روشهاى تجزيه هدف مى تواند اطلاعات مفيدى درباره مكانيسمهاى يراكنش فراهم كند. روشهاى تجزيه هدف به دو دور دسته

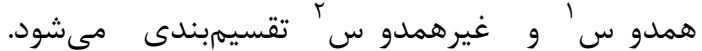
روشهاى تجزيه همدوس، ماتريس يراكنش را به مجموعهاى از ماتريسهاى يراكنش متناظر با اشياى

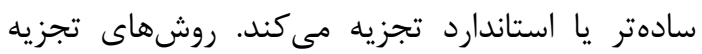
غيرهمدوس، ماتريس كواريانس يا همدوسى راسئ رأبه مجموعهاى از توصيفگرهاى درجه دوم متناظر با بان

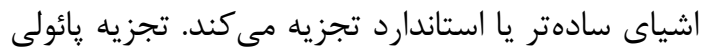
و كروFاكر نمونهاى از دسته اول و تجزيه فريمن؛

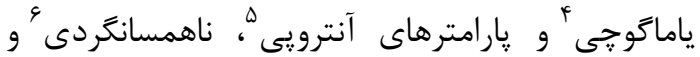

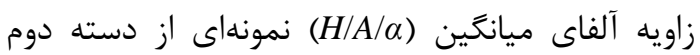

\section{r-r-1. ضرايب تجزيه يائولى}

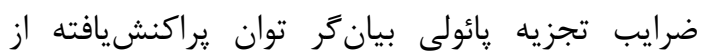

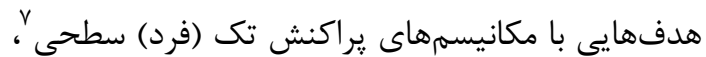

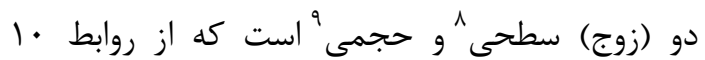

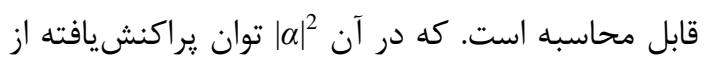

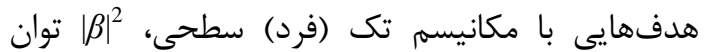
يراكنشيافته از هدفهايى با مكانيسم دو (زوج)

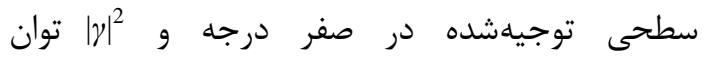
يراكنشيافته از هدفهايى با مكانيسم دو سطحى درجه

\footnotetext{
${ }^{1}$ Coherent

2 Incoherent

${ }^{3}$ Freeman

4 Yamaguchi

${ }^{5}$ Entropy

${ }^{6}$ Anisotropy

7 Single(Odd)-Bounce

${ }^{8}$ Double(Even)-Bounce

${ }^{9}$ Volume
} 
$|\alpha|^{2}=\left|\frac{S_{h h}+S_{v v}}{\sqrt{2}}\right|^{2}, \quad|\beta|^{2}=\left|\frac{S_{h h}-S_{v v}}{\sqrt{2}}\right|^{2}, \quad|\gamma|^{2}=2\left|S_{h v}\right|^{2}$

$\left|k_{s}\right|^{2}=\left|S_{r l}\right|^{2}, \quad\left|k_{d}\right|^{2}=\min \left(\left|S_{r r}\right|^{2},\left|S_{l l}\right|^{2}\right)$,

دوسطحى، حجمى و مارييجى تجزيه مى كند. همرجنين

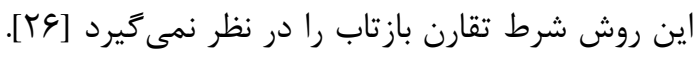

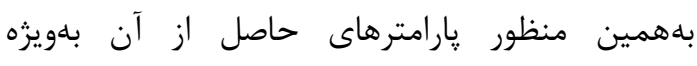

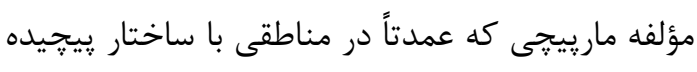

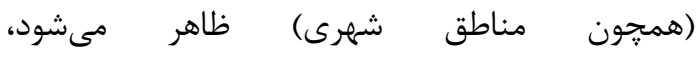

بهعنوان ويزگى هايى جهت شناسايى و تفكيك مناطق مناطق

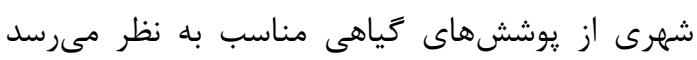

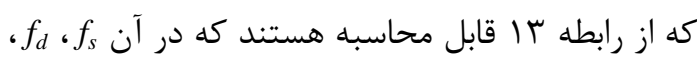
تك و f f $f_{c}$

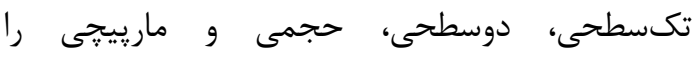
در ماتريس كواريانس نهايى نشان مى دهدي،

$P_{s}^{Y}=f_{s}\left(1+|\beta|^{2}\right), \quad P_{d}^{Y}=f_{d}\left(1+|\alpha|^{2}\right)$, يارامترهاى H/A/a از تجزيه بردار ويره ماتريس همدوسى به دست مى آيد كه از رابطه تجزيه

$H=-\sum_{i=1}^{3} p_{i} \log _{3}\left(p_{i}\right), \quad p_{i}=\frac{\lambda_{i}}{\sum_{k=1}^{3} \lambda_{k}}$

بهدستآمده از تجزيه بردار ويزه هستند.

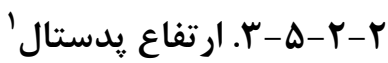

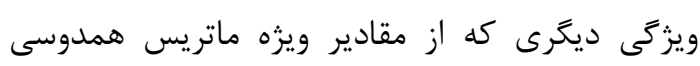

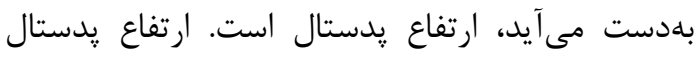

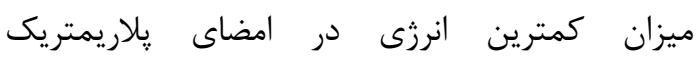

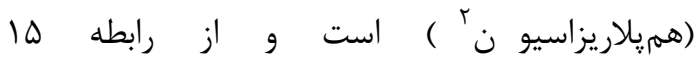

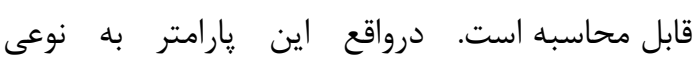

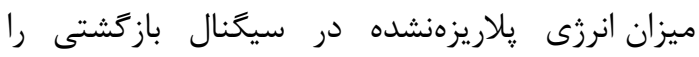

\footnotetext{
1 Pedestal Height

2 Co-pol
}

$$
\left|k_{h}\right|^{2}=a b s\left(\left|S_{r r}\right|^{2}-\left|S_{l l}\right|^{2}\right) \quad(1 \cdot) \quad(1) \quad \text { (ابطه }
$$

$$
P_{s}=f_{s}\left(1+|\beta|^{2}\right), \quad P_{d}=f_{d}\left(1+|\alpha|^{2}\right) \quad \text { رابطه (I ) }
$$
كه در آن كابن ،

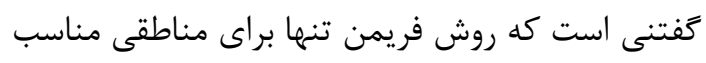

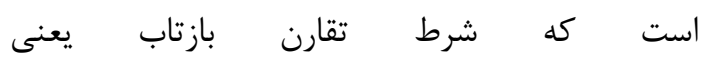
$\left\langle S_{h h} \cdot S_{h v}^{*}\right\rangle \approx\left\langle S_{h v} \cdot S_{v v}^{*}\right\rangle \approx 0$ بنابراين، ويزگى هاى حاصل از روش فريمن براى

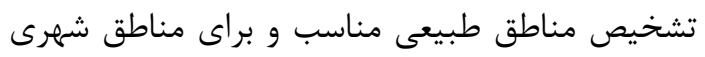

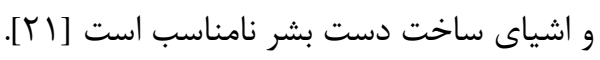
r-Y-Y

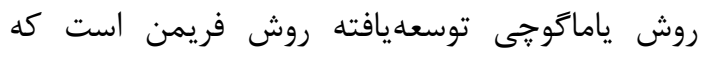

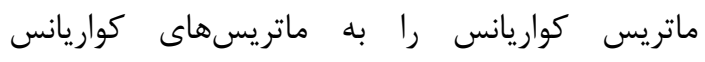

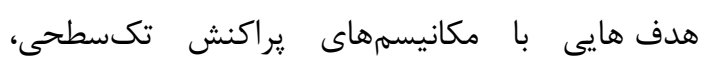
$P_{v}^{Y}=f_{v}, \quad P_{c}^{Y}=f_{c}$

رابطه (II)

r-r-ه. يارامترهاى حاصل از تجزيه بردار ويزه

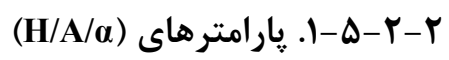
$A=\frac{\lambda_{2}-\lambda_{3}}{\lambda_{2}+\lambda_{3}}, \quad \bar{\alpha}=\sum_{i=1}^{3} p_{i} \alpha_{i}$ رابطه (1) قابل محاسبه است، كه در آن i ها ما مقادير ويزه ماتريس

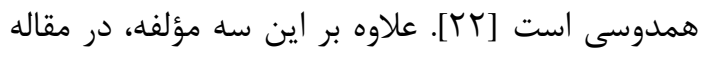

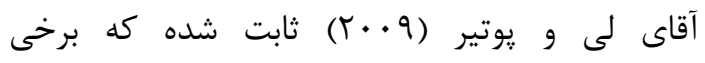
تركيبهاى $H$ و $A$ همجيون HA و (A) تركيبهاي

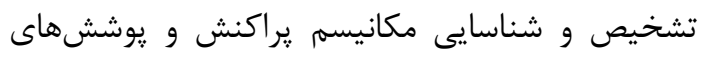

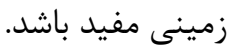

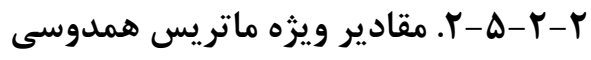

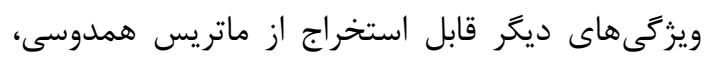

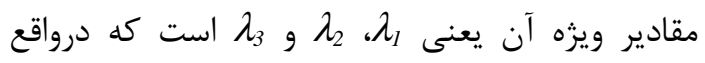
شاخص وزن هر يك از مكانيسمهاى يراكنش 


$$
\psi=\frac{\min \left(\lambda_{1}, \lambda_{2}, \lambda_{3}\right)}{\lambda_{1}+\lambda_{2}+\lambda_{3}}
$$

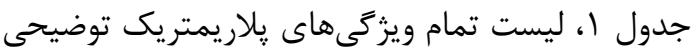

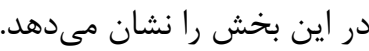

اندازمكيرى مى كند. اغلب يوششهاى كياهى از جمله

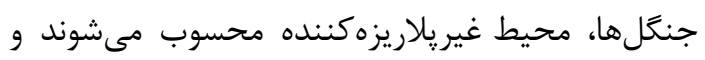
بنابراين مقدار ارتفاع ڤيدستال در اين نواحى بسيار

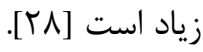

جدول rا: ويثَى هاى يلاريمتريك استخراجشده در اين مقاله

\begin{tabular}{|c|c|c|c|c|}
\hline \multicolumn{4}{|c|}{ نام و علامت ويثَى ها } & ويزَى ها \\
\hline ضريب همبستخى & 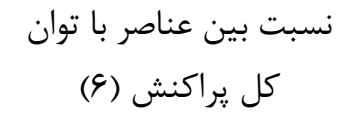 & نسبت بين عناصر يراكنش & شدت يسيراكنش دريافتى (() & \multirow{4}{*}{ 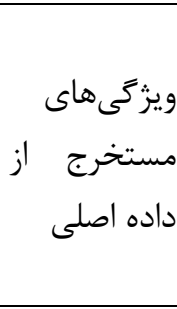 } \\
\hline \multirow[t]{3}{*}{ 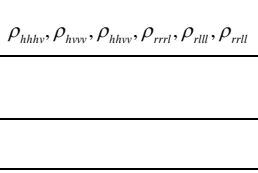 } & $R_{h h}, R_{h v}, R_{v v}, R_{r r}, R_{r l}, R_{l l}$ & $R_{h h l v,}, R_{h w w}, R_{h h w}, R_{r r t}, R_{r l l}, R_{r r l l}$ & $\sigma_{h h}, \sigma_{h v}, \sigma_{v v}, \sigma_{r r}, \sigma_{r l}, \sigma_{l l}$ & \\
\hline & & & عناصر قطرى ماتريس مولر (I) & \\
\hline & & & $M_{11}, M_{22}, M_{33}, M_{44}$ & \\
\hline ضرايب تجزيه & ضرايب تجزيه فريمن (r) & ضرايب تجزيه كروكاگر & ضرايب تجزيه يائولى (T) & \multirow{4}{*}{ 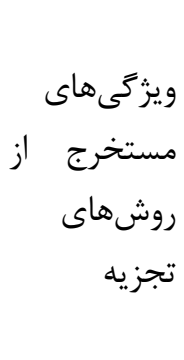 } \\
\hline \multirow[t]{3}{*}{$P_{s}^{Y}, P_{d}^{Y}, P_{v}^{Y}, P_{c}^{Y}$} & $P_{s}, P_{d}$ & $\left|k_{d}\right|^{2},\left|k_{h}\right|^{2}$ & $|\alpha|^{2},|\beta|^{2}$ & \\
\hline & يارامترهاى H/A/ & مقادير ويزه ماتريس (َ) همدوسى & ارتفاع يدستال ( ) & \\
\hline & $H, A, \bar{\alpha}, H A, H(1-A),(1-H) A,(1-H)(1-A)$ & $\lambda_{1}, \lambda_{2}, \lambda_{3}$ & $\psi$ & \\
\hline
\end{tabular}

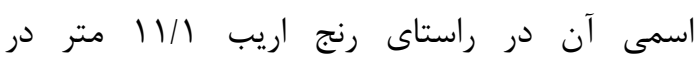

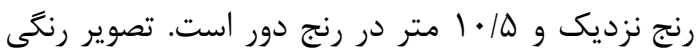

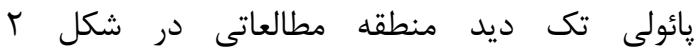
مشاهده مىشود.

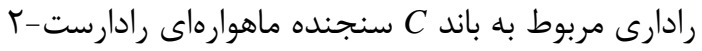
كرفتهشده از سانفرانسيسكو باى است. قدرت تفكيك لأن

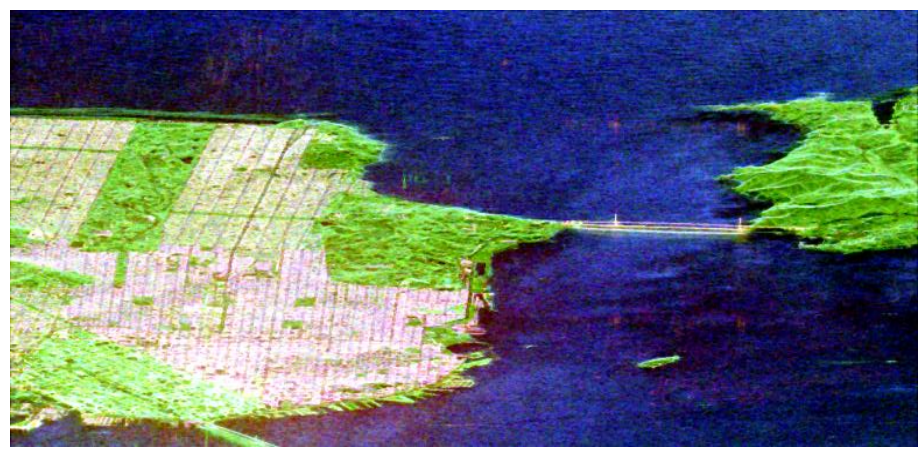

شكل 1. تصوير رنكى پائولى تك ديد منطقه مورد مطالعه: سانفرانسيسكو باى، ماهواره رادارست-T.

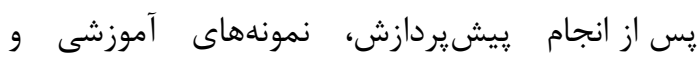
آزمايشى هر كلاس از منطقه مطالعاتى انتخاب ميىشودام.

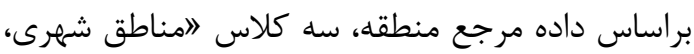
يوشش گياهى و آبه براى طبقابندى اين تصوير قبل از طبقهبندى، بايستى اسيكل موجود در تصوير

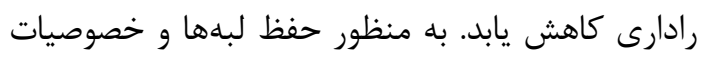

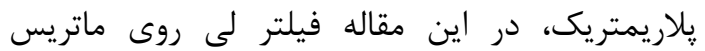
همدوسى تصوير موجود به كار مىرود [آس]. 


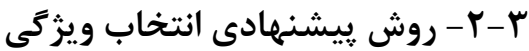

در اين بخش، با استفاده از الكَريتم GA و DT، اساس

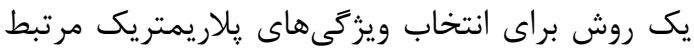

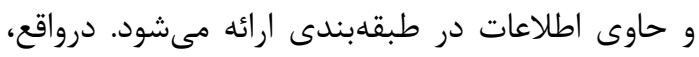

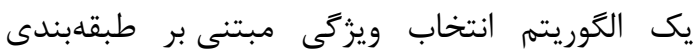

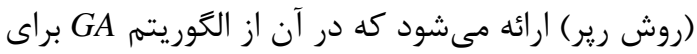

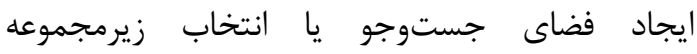

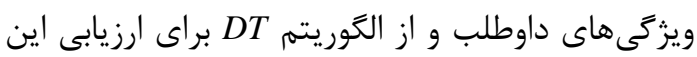

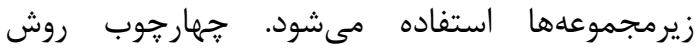
ي ״يشنهادى ارائهشه در شكل ا نشان داده شده است.
تعريف مىشود. جدول Y نام هر كلاس و تعداد

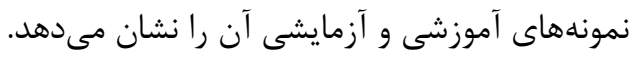

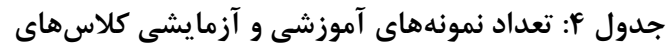

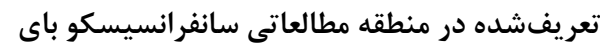

\begin{tabular}{|c|c|c|c|}
\hline آب & يوياهى & شهرى & كلاس \\
\hline $1 \Delta V$ & $14 q$ & Trt & \# نمونهاى آموزشى \\
\hline$\Delta q F$ & $\Delta V G$ & $\Delta \cdot 1$ & \# نمونههاى آزمايشى \\
\hline
\end{tabular}

بلمنظور ارزيابى بهتر روشها، تعداد نمونههاى آزمايشى آنسى

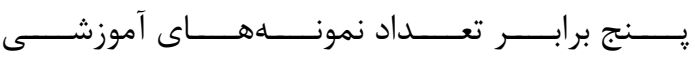
درنظر كرفته مىشود.

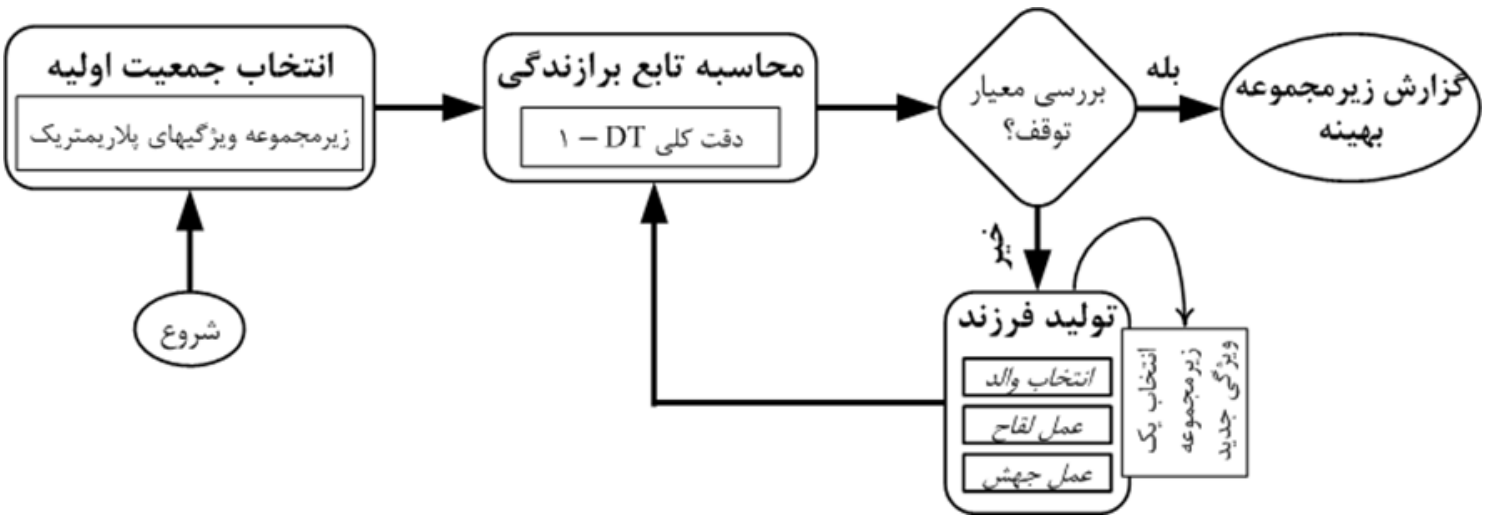

شكل ז: جهار جوب روش انتخاب ويزَى بيشنهادى در اين مقاله

ارزيابى (مشهور به تابع برازندگى ‘در زنتيك)، جمعيت

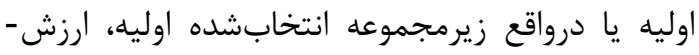

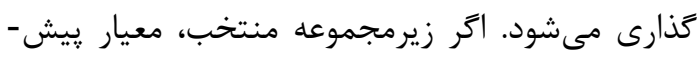

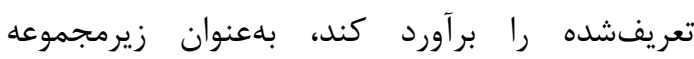

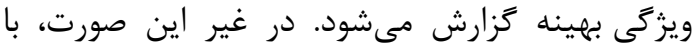

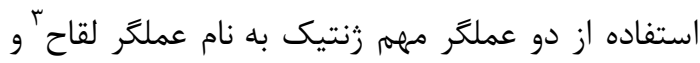

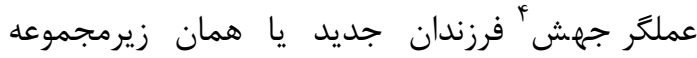

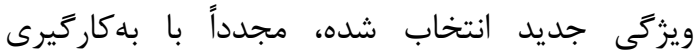
تابع ارزيابى، ارزش كذارى آن زيرمجموعه انجام شده و وداب

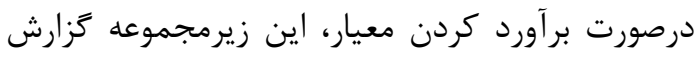

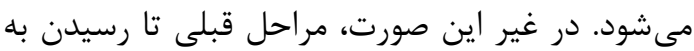

\footnotetext{
${ }^{2}$ Fitenss Function

${ }^{3}$ Cross-over

${ }^{4}$ Mutation
}

الگوريتم GA از جمله الگوريتمهاى بهينهسازى كارا و يراستفاده در يادگيرى ماشين و شناسايى الخو است. به

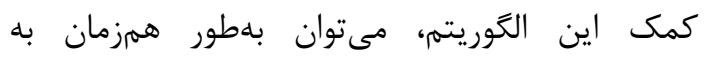
جستوجو در جندين نقطه از فضاى تمام حالات ممكن ويزگى ها يرداخت. مطابق با شكل ا، ابتدا در فضاى

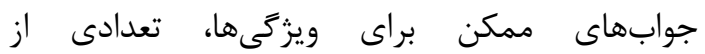
زيرمجموعههاى ويزگى بهعنوان جمعيت ' اوليه انتخاب مىشود. طول جمعيت برابر تعداد كل ويزگى هاى

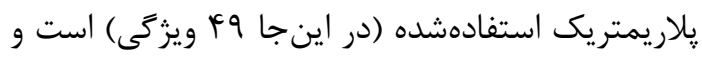
به صورت باينرى (· و ل (1) وارد الخوريتم مىشود؛ 1

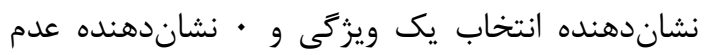
انتخاب آن ويزگگى است. سيس، با اعمال يكى تابع

\footnotetext{
${ }^{1}$ Population
} 
الطلاعاتى نمونههاى S براى ويزّى A و

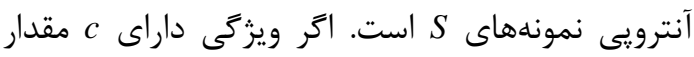

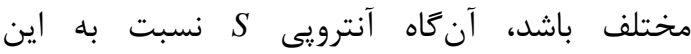
دستهبندى cكانه باصورت زير تعريف مىشود:

$$
H(S)=-\sum_{i=1}^{c} p_{i} \log _{2} p_{i}
$$

رابطه (I)

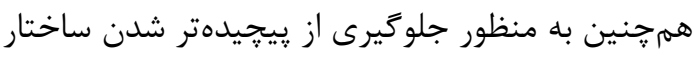
درخت از عمل هرس كردن درخت و كنار كذاشتن

شاخههاى اضافى و غيرضرورى استفاده مى كند [• آ]

$$
\text { F }
$$

علاوه بر نمايش رنكى پائولى در شكل זَ، برخى تركيب-

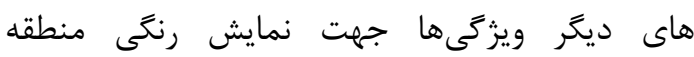
مطالعاتى در شكلهاى r مشاهده مىشود. همرجنين

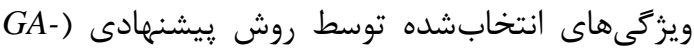
DT در جدول ץ نمايش داده شده است. براى ارزيابى روش بيشنهادى، آن را با طبقدبندى DT در حالت الت تمام

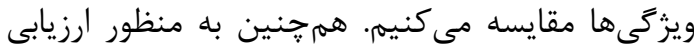

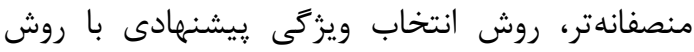

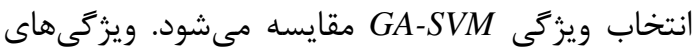
انتخابشده اين روش هم در جدول بَ آورده شده است.

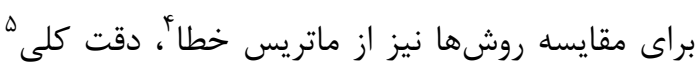

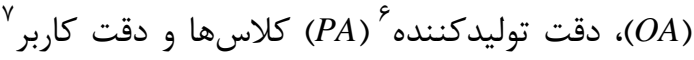
كلاسها (برمبناى نمونههاى آزمايشى) استفاده

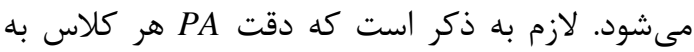

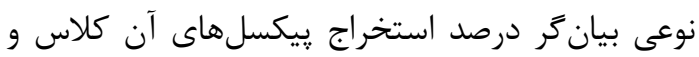
دقت UA هر كلاس به نوعى بيانكر نرخ اعتماديذيرى

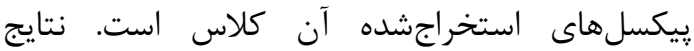

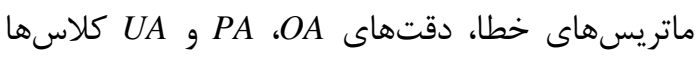
براى هر سه حالت در جدولهاى است. همرجنين جهت مقايسه بصرى دقت PA و

\footnotetext{
${ }^{4}$ Error Matrix

5 Overall Accuracy

${ }^{6}$ Producer's Accuracy

7 User's Accuracy
}

جواب نهايى ادامه مى يابد [جr].

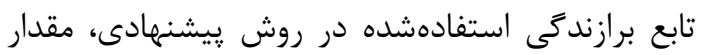

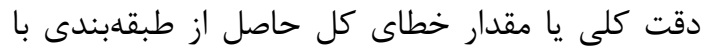
الكَوريتم DT روى نمونههاى آزمايشى است كه براى زيرمجموعه ويزگى بهينه انتخابشده، مقدار اولى

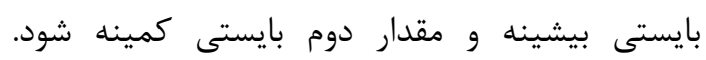

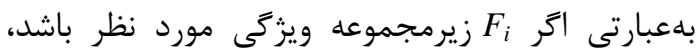

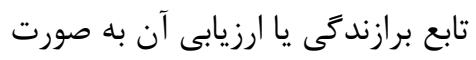
رابطه (1) قابل تعريف است كه در آن، FF تابع برازندكى و دقت كلى حاصل از طبقهبندى است.

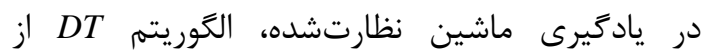
درختان براى نمايش بصرى تصميمها استفاده مى كند.

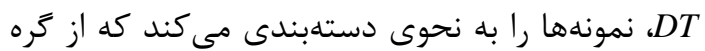

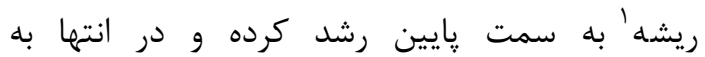

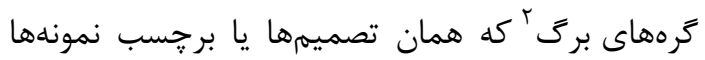

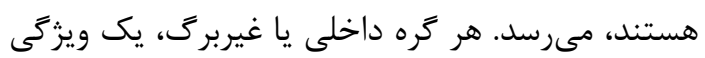
را نشان مىدهد كه به تعداد ارزش (يا مقدار) آن ويزگىى، شاخه از آن به كرههاى بإيينتر وجود دارد.

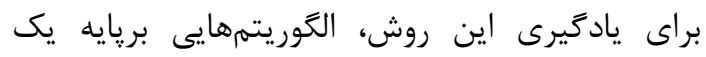

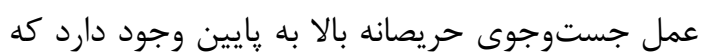
يكى از نمونههاى تكامليافته و كامل آن تحت عنوان

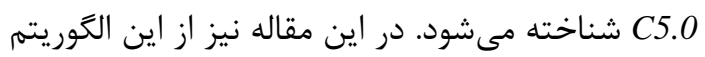
براى يادكيرى DT جهت طبقهبندى نمونهها استفاده

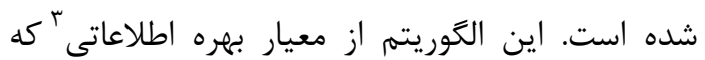

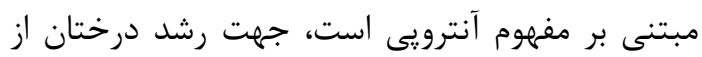

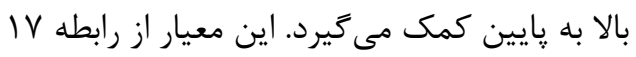
رابطه (IV)

$\operatorname{Gain}(S, A)=H(S)-\sum_{v \in \operatorname{Values}(A)} \frac{\left|S_{v}\right|}{|S|} H\left(S_{V}\right)$ قابل محاسبه است كه در آن Gain(S,A) بهره

\footnotetext{
${ }^{1}$ Root Node

${ }^{2}$ Leaf Node

${ }^{3}$ Information Gain
} 
نشريه علمى يُروهشى - مهندسى فناورى اطلاعات مكانى

كلاسها توسط هر سه حالت در شكلهاى F الف و أب ارائه شده است.

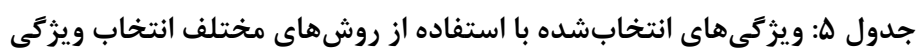

\begin{tabular}{|c|c|c|}
\hline تعداد ويز تَىها & ويزگَىهاى انتخابشده & روش انتخاب ويثزى \\
\hline V & $\lambda_{1}, \lambda_{3},|\beta|^{2}, R_{h h v v}, R_{l l}, \rho_{\text {rlll }}, \rho_{\text {rrll }}$ & يیشنهادى: الخوريتم GA-DT \\
\hline$\wedge$ & $A, H,|\beta|^{2}, R_{h v}, R_{r l r r}, \rho_{h h v v}, \sigma_{h h}, \sigma_{r r}$ & الخوريتم SVM \\
\hline
\end{tabular}

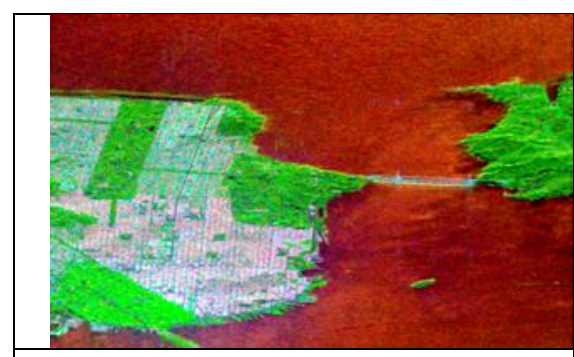

(")

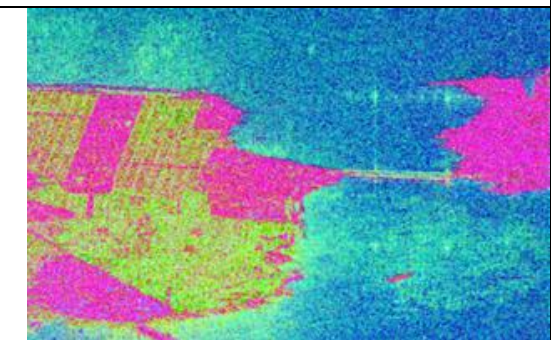

(g)

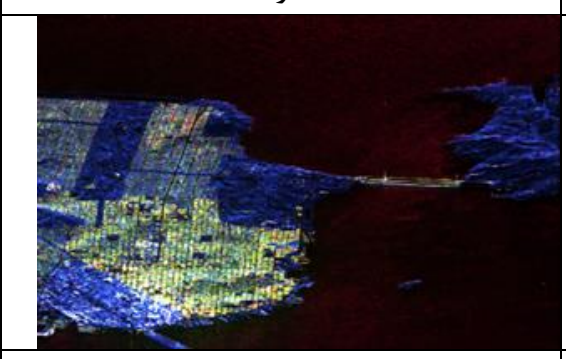

(b)

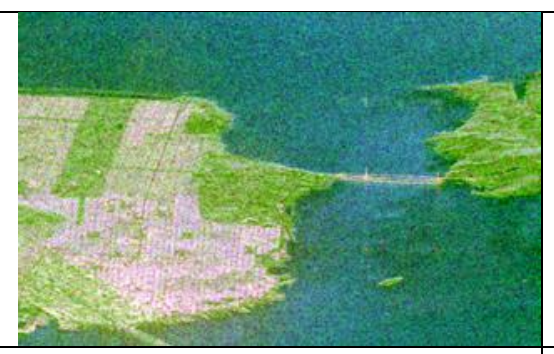

(ب)

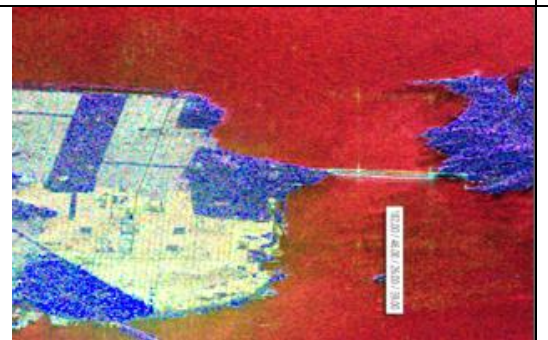

(0)

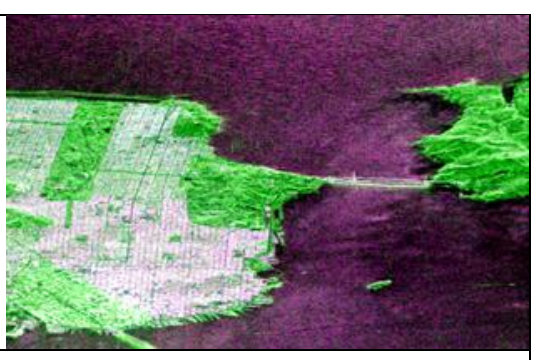

(الف)

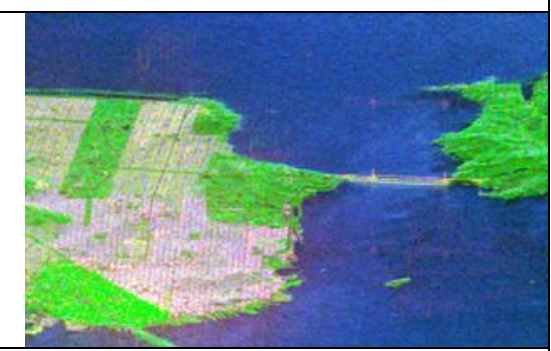

(ج)

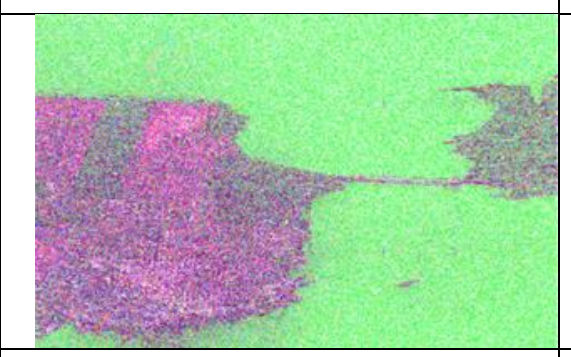

(ح)

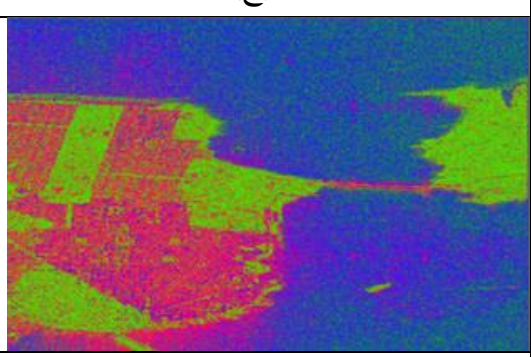

(j)

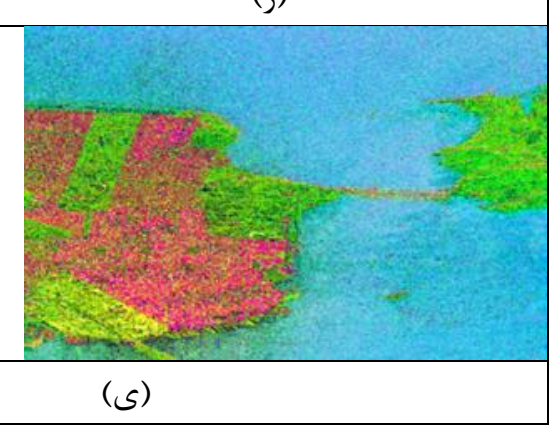

(ك)
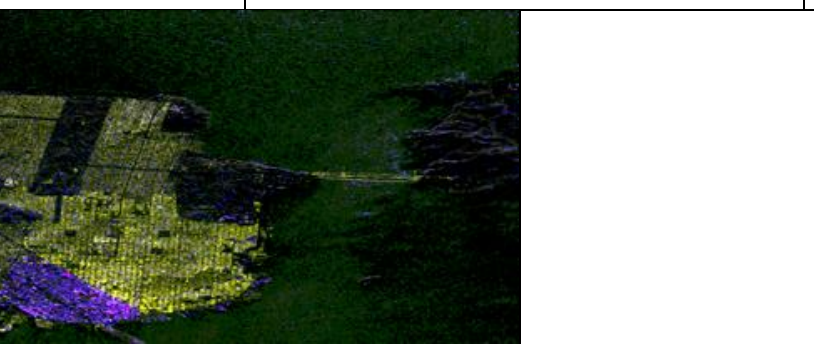

شكل س: نمايش هاى رنكى مختلف تصوير منطقه مطالعاتى. الف) تركيب رنكى سينكلر، ب) تركيب رنكى كروكاتر، ج) تركيب

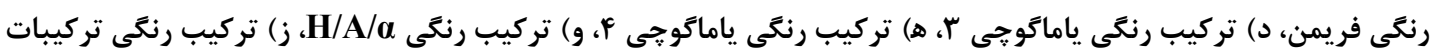

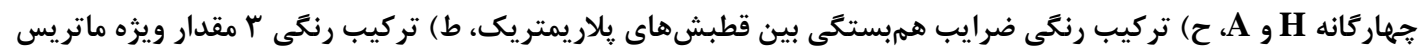

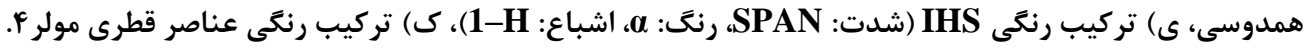




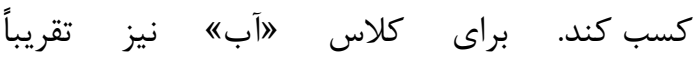
دقت توليدكننده دو روش يكسان شده است (شكل عالف). بنابراين مىتوان كفت كه بهطور كلى روش دوش

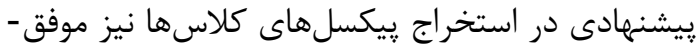

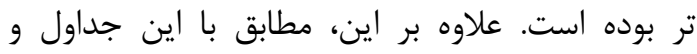
همرجنين با مشاهده شكل باب، دقت كاربر هر سه كلاس حاصل از روش يُشنهادى خيلى بيشتر (r)

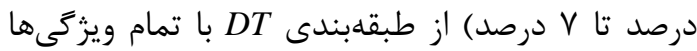
شده است كه اين مسئله بيانكر آن است كه نتايج

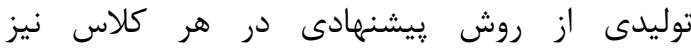

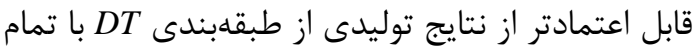
ويزگىىهاست. بنابراين براساس اين دو نتيجه مىتوان بيان كرد كه ويزگگهاى انتخابشده، حاوى اطلاعات

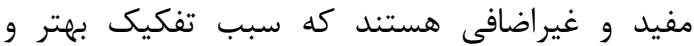
قابل اعتمادتر كلاسها از يكديكر شده است.
همانطور كه جداول F تا 9 نشان مىدهد، دقت كلى حاصل از طبقهبندى DT با تمام ويزكىها برابر بان

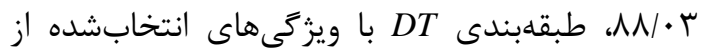

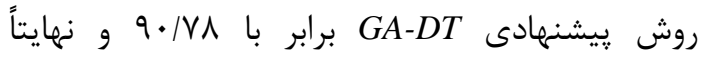

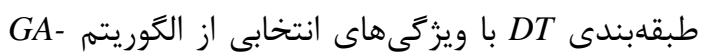
SVM روشهاى انتخاب ويزگى توانستهاند دقت بهترى نسبت

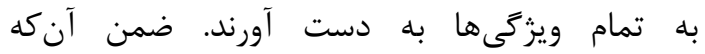
سرعت عمل طبقهبندى در اين دو حالت نيز نسبت به

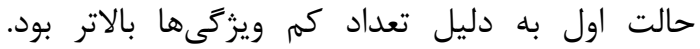

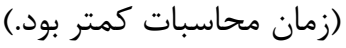

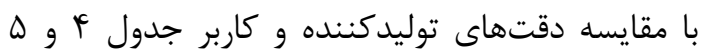
مشاهده مىشود كه براى كلاسهاى "شهرى و كياه"،

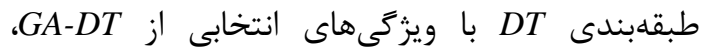

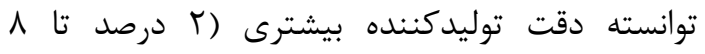
درصد) نسبت به طبقهبندى DT با تمام ويزگىها $\rightarrow{ }_{\rightarrow} \rightarrow \mathrm{DT}_{9} \mathrm{GA} \rightarrow \mathrm{SVM}_{9} \mathrm{GA}$
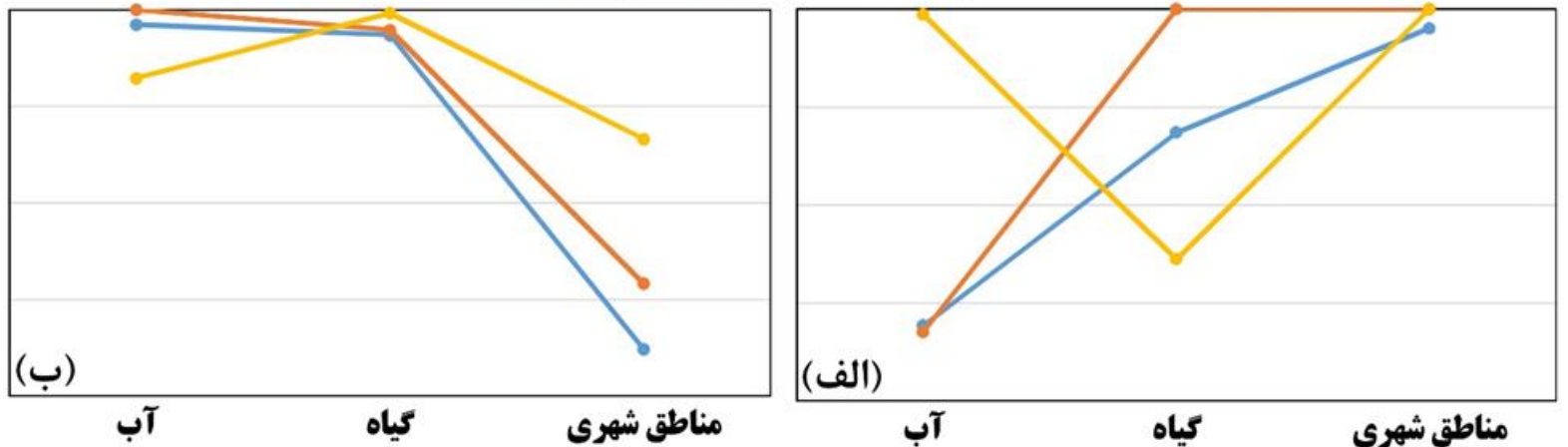

شكل F: نمودار دقتهاى حاصل از جهار روش اين مقاله، (الف) دقت توليدكننده (PA)، (ب) دقت كاربر (UA) (UA)

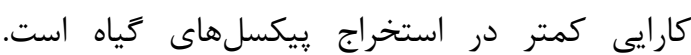

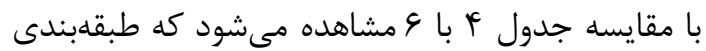

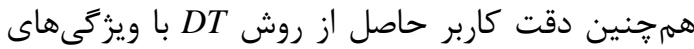

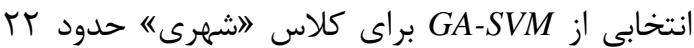
درصد و دقت كاربر كلاس " آياه" حدود ب درصد بيشتر از مقادير نظير آنها در روش DT با تمام ويزگى دارئ

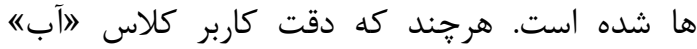
حاصل از حالت اول حدود \& درصد بيشتر از حالت سوم است. بنابراين بهطور ضمنى مىتوان بيان كرد كه اعتماديذيرى نتايج منطقه شهرى و گياه حاصل از روش DT با ويزگى هاى انتخابى از GA-SVM بيشتر از نتايج
DT با ويزگى هاى انتخابى از الكوريتم GA-SVM،

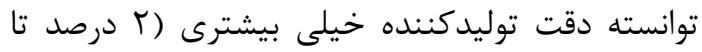

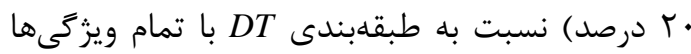
براى كلاسهاى "شهرى و آب" كسب كند. اما براى كلاس "كاياه" دقت توليدكننده آن حدود 1 درصد كمتر از حالت اول شده است. بنابراين مىتوان كَفت كه روش DT با ويزگى هاى انتخابى از

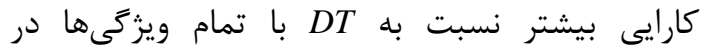
استخراج پيكسلهاى منطقه شهرى و آب و داراى 


$$
\text { مربوط از روش DT با تمام ويزگى هاست و براى آب اين مسئله برعكس است. }
$$

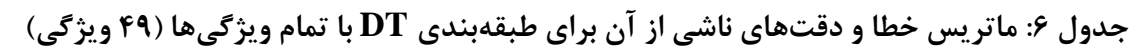

\begin{tabular}{|c|c|c|c|c|}
\hline $\boldsymbol{U A}$ & آب & حَياه & مناطق شهرى & \\
\hline GY/AV & (TV & rq & rTd & مناطق شهرى \\
\hline$q V / l^{c}$. & 11 & $\Delta \varphi)$ & f & كياه \\
\hline$q \wedge / \uparrow \wedge$ & $\Delta \wedge \Delta$ & 9 & - & آب \\
\hline$\Lambda \Lambda / \cdot r$ & V৭/AI & $q r / 1 T$ & 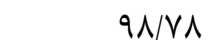 & $P A$ \\
\hline
\end{tabular}

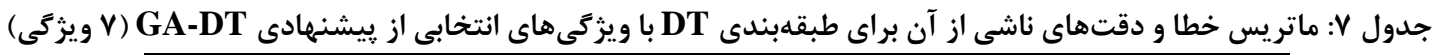

\begin{tabular}{|c|c|c|c|c|}
\hline $\boldsymbol{U A}$ & آب & كَياه & مناطق شهرى & \\
\hline$V 1 / 94$ & IFT & - & rबQ & مناطق شهرى \\
\hline $9 V / 9 r$ & IT & $\Delta S Y$ & - & كَياه \\
\hline $1 \cdots 1 \cdot$ & $\Delta q F$ & - & - & آب \\
\hline$q \cdot / \vee \wedge$ & $\left.V q / Y^{\prime}\right)$ & $1 \cdots 1 \cdot$ & $1 \cdots 1 \cdots$ & $\boldsymbol{P A}$ \\
\hline
\end{tabular}

جدول ^: ماتريس خطا و دقتهاى ناشى از آن براى طبقهبندى DT با ويزَكىهاى انتخابى از GA-SVM (A ويزَّى)

\begin{tabular}{|c|c|c|c|c|}
\hline $\boldsymbol{U A}$ & آب & كياه & مناطق شهرى & \\
\hline س & - & $\varepsilon V$ & pre & مناطق شهرى \\
\hline $99 / 90$ & $r$ & $\Delta V F$ & - & كَياه \\
\hline $9 r / 94$ & $\Delta \Delta r$ & er & . & آب \\
\hline$q u / r q$ & $99 / 94$ & $\Lambda F / \cdot r$ & $1 \cdots 1 \cdots$ & $P A$ \\
\hline
\end{tabular}

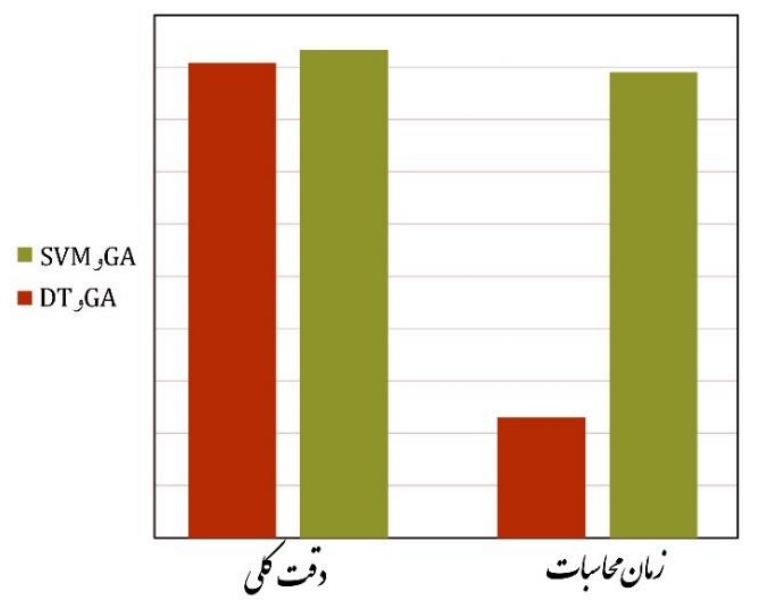

شكل ه: مقايسه بين زمان محاسبات و دقت كلى الكَوريتم SVM,GA با الكوريتم GA-DT

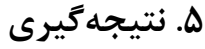

اين مقاله هماند بسيارى از مقالات نشان داد كه از يك لي
همرجنين مقايسه بين سرعت عملكرد و دقت كلى طبقهبندى DT با ويزگكىهاى انتخابى از

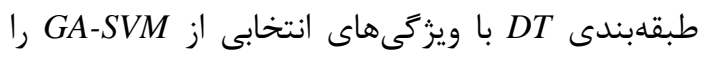

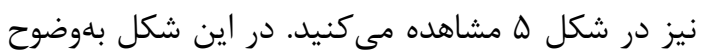
مشخص است كه دقت كلى روش بِيشنهادى اين مقاله يعنى طبقهبندى DT با ويزكى هاى انتخابى از تنهها حدود r درصد كمتر از دقت كلى طبقدبندى با ويزگى هاى انتخابى از GA-SVM است با اينحال،

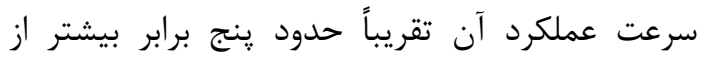

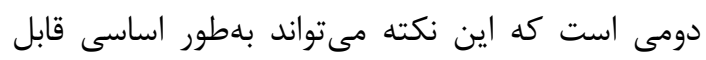
توجه باشد. درواقع الكَوريتم بِيشنهادى اين مقاله توانسته با سرعت خيلى بيشتر و دقت كلى تقريباً برابر

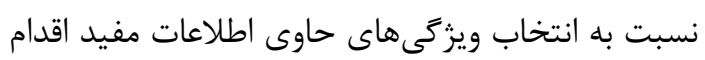




$$
\begin{aligned}
& \text { تفكيك مناطق "شهرى و كياه" و ويزگى هاى } \\
& \text { انتخاب شده توسط الكوريتم GA-SVM در تفكيك } \\
& \text { مناطق "شهرى و آب" موفقتر از ساير مناطق }
\end{aligned}
$$

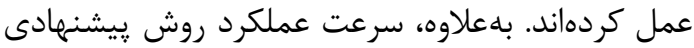

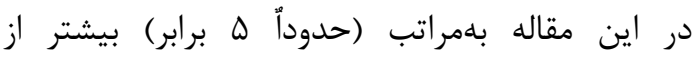

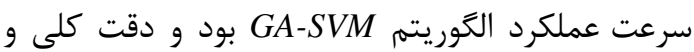

$$
\begin{aligned}
& \text { اكثر دقتهاى كاربرى و توليدى آن نيز نسبت به حالت } \\
& \text { "اتمام ويزَى هاه خيلى بهتر بود. }
\end{aligned}
$$

[1] C. Lardeux, P-L. Frison, C. Tison, J-C. Souyris, B. Stoll, B. Fruneau, and J-P. Rudant, "Support vector machine for multifrequency SAR polarimetric data classification," IEEE Trans. Geosci. Remote Sens., vol. 47, no. 12, pp. 4143-4152, 2009.

[2] J.A. Kong, A.A. Swartz, et al. "Identification of terrain cover using the optimal terrain classifier," J. Electromagn. Waves Applicat. vol. 2, pp. 171-194, 1988.

[3] J.J. Van Zyl and C.F. Burnette, "Baysian classification of polarimetric SAR images using adaptive a apriori probability," Int. J. Remote Sens. vol. 13, no.5, pp. 835-840, 1992.

[4] E. Rignot, R. Chellappa, and P. Dubois, "Unsupervised segmentation of polarimetric SAR data using the covariance matrix," IEEE Tran. Geosci. Remote Sens. vol. 30, no. 4, pp. 697-705, July 1992.

[5] J.S. Lee, M.R. Grues, and R. Kwok, "Classification of multi-look polarimetric SAR imagery based on complex wishart distribution,” Int. J. Remote Sens. vol. 15, pp. 2299-2311, 1994.

[6] L. Ferro-Famil, E. Pottier, and J.S. Lee, "Unsupervised classification of multifrequency and fully polarimetric SAR images based on H/A/Alpha-wishart classifier," IEEE Trans. Geosci. Remote Sens. vol. 39, no. 11, pp. 2332-2342, November 2001.

[7] T. Moriyama, S. Uratsuka, T. Umehara, M.

$$
\begin{aligned}
& \text { تصوير تمام يلاريمتريك رادارى، استخراج ويزگىهاى }
\end{aligned}
$$

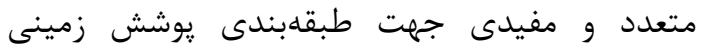

$$
\begin{aligned}
& \text { امكانيذير است. در اين مقاله، با استفاده از الكوريته }
\end{aligned}
$$

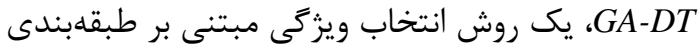

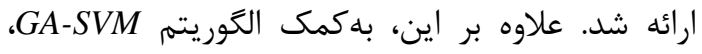

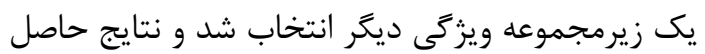

$$
\begin{aligned}
& \text { از طبقهبندى با اين ويزگىها با حالت اول مقايسه } \\
& \text { كرديد. طبق اين نتايج مىتوان بهطور كلى بين بيان كرد كه }
\end{aligned}
$$

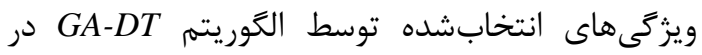

$$
\begin{aligned}
& \text { مراجع }
\end{aligned}
$$

Satake, A. Nadai, H. Maeno, K. Nakamura, and Y. Yamaguchi, "A study on extraction of urban areas from polarimetric synthetic aperture radar image," in Proc. of IGARSS'04, vol.1, pp.703-706, 2004.

[8] C.J. Song, S. Yun, and L. Hui, "Classification of polarimetric SAR imagery based on target decomposition and neural network classifier," In Proc. of ACRS '04, November, 2004.

[9] V. Alberga, "Comparison of polarimetric methods in image classification and SAR interferometry applications," Ph.D. dissertation, Tech. Univ. Chemnitz, Chemnitz, Germany, 2005.

[10] C. Lardeux, P.-L. Frison, J.-P. Rudant, J.-C. Souyris, C. Tison, and B. Stoll, "Use of the SVM classification with polarimetric SAR data for land use cartography," in Proc. ofIGARSS'06, July 31- August 04, Denver, Colorado, 2006.

[11]I. Khosravi, and M. Mohammad-Beigi, "Multiple classifier systems for hyperspectral remote sensing data classification," J. the Indian Society of Remote Sens., 42(2), pp. 423-428, 2014.

[12]Y. Maghsoudi, M.J. Collins, and D.G. Leckie, "Radarsat-2 polarimetric SAR data for Boreal forest classification using SVM and a wrapper feature selector," IEEE J. Selected Topics in Appl. Earth Observ. Remote Sens., vol. 6, no. 3, pp. 1531-1538, 2013. 
[13] A. Haddadi, M.R. Sahebi, and A. Mansourian, "Polarimetric SAR feature selection using a genetic algorithm," Canadian J. Remote Sens., vol. 37, no. 1, pp. 27-36, 2011.

[14]M. Salehi, M.R. Sahebi, and Y. Maghsoudi, "Improving the accuracy of urban land cover classification using Radarsat-2 POLSAR data," IEEE J. Selected Topics in Appl. Earth Observ. Remote Sens., vol. 7, no. 4, pp. 1394-1401, 2014.

[15]Z. Qi, A. G. Yeh, X. Li, and Z. Lin, “A novel algorithm for land use and land cover classification using RADARSAT-2 polarimetric SAR data," Remote Sens. Environ., vol. 118, pp. 21-39, 2012.

[16]L. Pipia, V. Alberga, M. Chandra, M. Migliaccio, and K.B. Khadra, "Quantitative assessment of the efficiency of supervised classification using coherent and incoherent polarimetric SAR observables," In Proc. of EUSAR 2002, pp. 729-732, Cologne, Germany, June 2002.

[17] V. Alberga and M. Chandra, "Analysis of amplitude ratios in SAR polarimetry," In Kleinheubacher Berichte 2000, pp. 527-534, Kleinheubacher, Germany, September 2000.

[18] T.A. Seliga, V.N. Bringni, and H.H. AlKhatib, "Differential reflectivity measurements in rain: first experiments," IEEE Trans. Geosci. Remote Sens. vol. 17, no. 4, pp. 240-244, October 1979.

[19]J.C. Curlander, and R.N. McDonough, "Synthetic aperture radar, systems and signal processing," John Wiley and Sons, New York, USA, 1991.

[20]H. Aoki, M. Matsuoka, and F. Yamazaki, "Backscattering characteristics of airborne SAR images for seismic vulnerability assessment in urban areas," In Proc. of ACRS '99, November, 1999.

[21] S.V. Nghiem, S.H. Yueh, R. Kwok, and F.K. $\mathrm{Li}$, "Symmetry properties in polarimetric remote sensing," Radio Science, vol. 27, no. 5, pp. 693-711, September 1992.

[22]H.A. Zebker, J.J. vanZyl, "Imaging radar polarimetry: a review," Proc. IEEE, vol. 79, no. 11, pp. 1583-1606, November 1991.

[23] S.R. Cloude and E. Pottier, "A review of target decomposition theorems in radar polarimetry," IEEE Trans. Geosci. Remote Sens., vol. 34, pp. 498-518, Mar. 1996.

[24]E. Krogager, "A new decomposition of the radar target scattering matrix," Electron. Lett., vol. 26, no. 18, pp. 1525-1526, 1990.

[25]A. Freeman and S. Durden, "A threecomponent scattering model to describe polarimetric SAR data," in Proceedings SPIE Conference on Radar Polarimetry, Vol. 1748, pp. 213-225, San Diego, CA, July 1992.

[26] Y. Yamaguchi, T. Moriyama, M. Ishido, and H. Yamada, "Four-component scattering model for polarimetric SAR image decomposition," IEEE Trans. Geosci. Remote Sens., vol. 43, no. 8, pp. 1699-1706, August 2005.

[27] J.S. Lee and E. Pottier, "Polarimetric radar imaging: from basics to applications," CRC Press, Taylor and Francis Group, New York, 2009.

[28] K.M. Rodriguez, J.K. Weissel, and Y. Kim, "Classification of landslide surfaces using fully polarimetric SAR: examples from Taiwan," In International Geoscience and Remote Sensing Symposium (IGARSS) 5:2918-2920, 2002.

[29]B. Bhanu, and Y. Lin, "Genetic algorithm based feature selection for target detection in SAR images," Image and Vision Computing, vol. 21(7), pp. 591-608, July 2003.

[30]C. M., Bishop, "Pattern Recognition and Machine Learning," Springer, Second Edition, pp. 663-666, 2006.

[31] J. S. Lee, M. R. Grunes, and G. de Grandi, "Polarimetric SAR speckle filtering and its implication for classification," IEEE Trans. Geosci. Remote Sens., vol. 37, no. 5, pp. 2363-2373, 1999. 


\title{
Presenting A Feature Selection Method Based On Genetic Algorithm and Decision Tree For Classifying Fully Polarimetric SAR Images
}

\author{
Iman Khosravi $*^{1}$, Mir Majid Mousavi ${ }^{2}$, Jalal Amini ${ }^{3}$
}

1- PhD. student of remote sensing in School of Surveying and Geospatial Engineering, College of Engineering, University of Tehran

2- MA in remote sensing in School of Surveying and Geospatial Engineering, College of Engineering, University of Tehran

3- Associate professor in School of Surveying and Geospatial Engineering, College of Engineering, University of Tehran

\begin{abstract}
A fully polarimetric synthetic aperture radar (POLSAR) image can provide important polarimetric features for land cover classification. These features can be the parameters obtained from scatering, covariance and coherency matrices, parameters extracted from target decomposition methods or both of them. In this paper, many polarimetric features are extracted from a POLSAR image. Then, with the use of Genetic Algorithm (GA) and Decision Tree (DT), a feature selection method based on the classification is presented. Afterwards, a comparative analysis is accomplished between DT classification with features selected from the proposed method and DT classification with all features. Moreover, the proposed method should be compared with the feature selection method of GA and Support Vector Machine (SVM). The results indicated that the accuracy of the proposed method (DT classification with the features selected from GA-DT algorithm) is nearly $3 \%$ higher than the ones of the DT classification with all features and it is approximately equal with the ones of the DT classification with the features selected from GA-SVM algorithm. However, the performance speed of the proposed method is approximately 5 times more than the ones of DT classification with the features selected from GA-SVM algorithm. As an another result, the features selected from the proposed method have a more success than the ones of two other methods at classifying the urban areas and vegetation classes.
\end{abstract}

Key words: Regional gravity field modeling, Spherical Radial Basis Functions, Genetic algorithm, Tikhonov algorithm.

Correspondence Address Remote Sensing Division, School of Surveying and Geospatial Engineering, College of Engineering, University of Tehran, Tehran, I.R. Iran. Tel: +989183666975.

Email: iman.khosravi@ut.ac.ir 